\title{
PERBEDAAN PENGARUH KACANG TANAH (ARACHIS HYPOGAEA) REBUS DAN PANGGANG TERHADAP KADAR KOLESTEROL LDL, HDL PADA WANITA OVERWEIGHT - OBESITAS
}

\author{
Denada Stefiani, Yekti Wirawanni" \\ Program Studi Ilmu Gizi Fakultas Kedokteran Universitas Diponegoro \\ J1.Dr.Sutomo No.18, Semarang, Telp (024) 8453708, Email : gizifk@ undip.ac.id
}

\begin{abstract}
Background : Overweight is a states in which the weight exceeds a standard based on height whereas obesity refers to an excess amount of adipose tissue. WHO classify individuals with a BMI of $\geq 23.00 \mathrm{~kg} / \mathrm{m}^{2}$ as overweight and those with a BMI of $>25.00 \mathrm{~kg} / \mathrm{m}^{2}$ as obese. Overweight and obesity can effect to $L D L-C$ raising and $H D L-C$ lowering. Peanuts contain MUFA, PUFA, and fiber which is effect the LDL-C and HDL-C. The aim of this study is to know difference effects of boiled and dry roasted peanuts on serum $L D L-C$ and $H D L-C$ in women with overweight-obesity.

Methods : This research was true experimental study with randomized pre-post group design. Subjects were 16 women with $L D L-C$ level $\geq 130 \mathrm{mg} / \mathrm{dl}$ and $H D L-C$ level $\leq 60 \mathrm{mg} /$ dl. Subjects were classified into 2 group intervention. The first group consumed boiled peanuts and the second group consumed dry roasted peanuts. Each groups consumed $77 \mathrm{~g}$ peanuts during 4 weeks. LDL-C level was measured with Friedawald equation and HDL-C level was analyzed by phosphotungstic precipilation method. Each blood sample was taken after $10 \mathrm{~h}$ fasting period. Normality test used Shapiro-Wilk. Statistic analyze for normal data used Paired t-test and Independent t-test, for abnormal data used Mann-Whitney and Wilcoxon.

Results : Consumption of boiled peanuts and dry roasted peanuts can reduce LDL-C respectively $4.12 \pm 16.40 \mathrm{mg} / \mathrm{dl}$ $(p>0.05)$ and $24.15 \pm 25.07 \mathrm{mg} / \mathrm{dl}(p<0.05)$. There was no significant difference in the LDL-lowering effect between the-2 groups ( $p>0.05)$. Consumption of boiled peanuts can reduce HDL-C 3.87 $\pm 7.71 \mathrm{mg} / \mathrm{dl}(\mathrm{p}>0.05)$ whereas dry roasted peanuts can increased $H D L-C 2.00 \pm 6.09 \mathrm{mg} / \mathrm{dl}$. There was no significant difference in the $H D L-C$ effect between the-2 groups ( $p>0.05$ ).

Conclusion : There was no significant difference in the LDL-C lowering and HDL-C increasing effect between the2 groups $(p>0.05)$.
\end{abstract}

Keywords : Peanuts; LDL cholesterol; HDL cholesterol; women; overweight; obesity

\begin{abstract}
ABSTRAK
Latar Belakang : Overweight adalah suatu kondisi dimana terjadi berat badan berlebih bila diukur berdasarkan tinggi badan sedangkan obesitas adalah suatu kondisi dimana terjadi akumulasi jaringan lemak yang berlebih. Klasifikasi overweight dan obesitas menurut WHO berdasarkan kriteria Asia Pasifik secara berturut-turut yaitu $\geq$ $23.00 \mathrm{~kg} / \mathrm{m}^{2}$ dan $>25.00 \mathrm{~kg} / \mathrm{m}^{2}$. Overweight dan obesitas ini berpengaruh terhadap tingginya kadar kolesterol LDL dan rendahnya kadar kolesterol HDL. Kacang tanah mengandung MUFA, PUFA, dan serat yang berpengaruh terhadap kadar kolesterol LDL dan HDL. Penelitian ini bertujuan untuk mengetahui perbedaan pengaruh kacang tanah rebus dan panggang terhadap kadar kolesterol LDL dan HDL pada wanita overweight-obesitas.

Metode : Jenis penelitian adalah true experimental dengan rancangan randomized pre-post group design. Subyek adalah 16 wanita overweight - obesitas dengan kadar kolesterol LDL $\geq 130 \mathrm{mg} /$ dl dan atau kadar kolesterol HDL $\leq$ $60 \mathrm{mg} / \mathrm{dl}$. Subyek dibagi ke dalam 2 kelompok perlakuan. Kelompok perlakuan 1 mendapatkan intervensi kacang tanah rebus dan kelompok perlakuan 2 mendapatkan kacang tanah panggang. Tiap kelompok mendapatkan intervensi kacang tanah sebanyak 77 gram selama 4 minggu. Kadar kolesterol LDL dianalisis menggunakan metode perhitungan rumus Friedawald dan kadar kolesterol HDL dianalisis menggunakan metode phosphotungstic precipilation. Pengambilan darah subyek dilakukan setelah subyek berpuasa selama 10 jam. Data yang diperoleh diuji normalitasnya menggunakan uji Shapiro-Wilk setelah itu dianalisis menggunakan uji paired t-test, MannWhitney, independent t-test, dan Wilcoxon.

Hasil : Pemberian kacang tanah rebus dan panggang sebanyak 77 gram selama 4 minggu berturut-turut menurunkan kadar kolesterol LDL sebesar $4.12 \pm 16.40 \mathrm{mg} / \mathrm{dl}(p>0.05)$ dan 24.15 $\pm 25.07 \mathrm{mg} / \mathrm{dl}(p<0.05)$. Tidak terdapat perbedaan penurunan kadar LDL antara kedua kelompok ( $p>0.05)$. Pemberian kacang tanah rebus dapat menurunkan kadar HDL sebesar 3.87 $\pm 7.71 \mathrm{mg} / \mathrm{dl}(\mathrm{p}>0.05)$ sedangkan kacang tanah panggang dapat meningkatkan kadar HDL sebesar $2.00 \pm 6.09 \mathrm{mg} / \mathrm{dl}(\mathrm{p}>0.05)$. Tidak terdapat perbedaan peningkatan kadar HDL antara kedua kelompok $(p>0.05)$.
\end{abstract}

Kesimpulan : Tidak terdapat perbedaan penurunan kadar kolesterol LDL dan peningkatan kadar kolesterol HDL antara kedua kelompok perlakuan ( $p>0.05)$.

${ }^{*}$ Penulis Penanggungjawab 
Kata Kunci : Kacang tanah; Kolesterol LDL; HDL; overweight; obesitas

\section{PENDAHULUAN}

Overweight adalah suatu kondisi dimana terjadi berat badan yang berlebih bila diukur berdasarkan tinggi badan sedangkan obesitas adalah suatu kondisi dimana terjadi akumulasi jaringan lemak yang berlebih. Overweight dan obesitas dapat terjadi karena adanya ketidakseimbangan energi dalam tubuh. Pengukuran yang biasa digunakan untuk mengetahui status kondisi tersebut adalah Indeks Massa Tubuh (IMT) atau Body Mass Index (BMI), yang didapat dengan cara membagi berat badan (kg) dengan kuadrat dari tinggi badan (meter). Berdasarkan WHO, klasifikasi overweight dan obesitas berdasarkan IMT menurut kriteria Asia Pasifik secara berturut-turut yaitu $\geq 23.00 \mathrm{~kg} / \mathrm{m}^{2}$ dan $>25.00 \mathrm{~kg} / \mathrm{m}^{2} .1,2$,

Berdasarkan data World Health Organization (WHO) pada tahun 2008 tentang prevalensi usia > 20 tahun yang mengalami obesitas diketahui bahwa di Indonesia, perempuan (6.9\%) berisiko lebih tinggi mengalami obesitas dibandingkan laki-laki $(2.5 \%){ }^{3}$ Berdasarkan laporan RISKESDAS tahun 2010, diketahui bahwa sebesar $21.7 \%$, masalah gizi penduduk dewasa di atas 18 tahun adalah overweight dan obesitas. Berdasarkan jenis kelamin, prevalensi obesitas pada perempuan (26.9\%) lebih tinggi dibandingkan dengan laki-laki (16.3\%). ${ }^{4}$

Overweight dan obesitas ini berpengaruh terhadap tingginya kadar kolesterol LDL dan rendahnya kadar kolesterol HDL. Hal ini dapat memicu terjadinya proses atherosclerosis yang merupakan faktor resiko terjadinya penyakit kardiovaskuler. ${ }^{1,2,5}$ Beberapa cara dapat dilakukan untuk mencegah terjadinya penyakit kardiovaskuler seperti olah raga, terapi medis, dan terapi diet. ${ }^{6}$ Beberapa terapi diet yang dapat diterapkan yaitu dengan cara membatasi asupan makanan yang mengandung tinggi lemak jenuh dan mengkonsumsi bahan makanan yang dapat membantu menurunkan kadar kolesterol darah seperti kacang tanah. ${ }^{6,7}$

Kacang tanah (Arachis hypogaea) merupakan salah satu jenis kacang-kacangan yang mengandung Mono Unsaturated Fatty Acid (MUFA), Poly Unsaturated Fatty Acid (PUFA), magnesium, folat, $\alpha$-tocopherol, arginin, flavonoid, isoflavone, resveratol, serat, dan fitosterol. ${ }^{7,8,9}$ Beberapa kandungan pada kacang tanah yang diketahui dapat menurunkan kadar kolesterol LDL dan meningkatkan kadar kolesterol HDL yaitu
Mono Unsaturated Fatty Acid (MUFA), Poly Unsaturated Fatty Acid (PUFA), dan serat. Kacang tanah termasuk sebagai sumber Mono Unsaturated Fatty Acid (MUFA) yang kandungannya lebih tinggi daripada PUFA. Berdasarkan penelitian sebelumnya diketahui bahwa diet tinggi MUFA yaitu $10 \%$ dari total energi dapat menurunkan kadar kolesterol LDL sampai dengan $14 \% .^{10,11}$

Penelitian di Iran tahun 2009 dilakukan pemberian kacang tanah panggang sebanyak 77 gram selama 4 minggu pada 54 orang laki-laki penderita hiperkolesterolemia. Berdasarkan penelitian tersebut diketahui bahwa terjadi penurunan kadar kolesterol LDL sebesar $4.11 \%$ dan peningkatan kadar kolesterol HDL sebesar $18.2 \% .^{8}$ Penelitian tersebut hanya meneliti tentang pengaruh pemberian kacang tanah dengan proses yang dipanggang terhadap profil lipid pada lakilaki hiperkolesterolemia, namun penelitian tentang pengaruh cara pemasakan kacang tanah dengan cara direbus dan dipanggang terhadap kadar kolesterol LDL dan HDL pada wanita belum ada. Proses pemasakan kacang tanah dengan cara direbus lebih sering dilakukan oleh masyarakat di Indonesia dalam mengolah kacang tanah karena prosesnya yang cukup mudah. Penelitian ini lebih ditujukan untuk mengetahui perbedaan kacang tanah yang direbus dan dipanggang terhadap kadar kolesterol LDL dan HDL pada wanita overweightobesitas.

\section{METODE}

Penelitian ini merupakan penelitian true experimental dengan rancangan randomized prepost group design. Penelitian ini memberikan intervensi khusus pada kelompok perlakuan 1 dan kelompok perlakuan 2, oleh karena itu penelitian ini dilaksanakan setelah mendapat persetujuan dari Komite Etik Fakultas Kedokteran Universitas Diponegoro dalam bentuk Ethical Clearance. Variabel bebas dalam penelitian ini yaitu pemberian kacang tanah rebus dan kacang tanah panggang, sementara variabel terikat dalam penelitian ini yaitu kadar kolesterol LDL dan kadar kolesterol HDL.

Subyek penelitian ini adalah karyawati di Gedung Pandanaran Semarang dan karyawati Kantor Sekretariat Daerah Provinsi Jawa Tengah. Kriteria inklusi pada penelitian ini yaitu karyawati yang berusia minimal 30 tahun, memiliki kadar kolesterol LDL $\geq 130 \mathrm{mg} / \mathrm{dl}$ dan atau kadar kolesterol HDL $\leq 60 \mathrm{mg} / \mathrm{dl}$, memiliki Indeks 
Massa Tubuh (IMT) $\geq 23,0 \mathrm{~kg} / \mathrm{m}^{2}$, belum mengalami menopause, tidak sedang mengkonsumsi obat antihiperlipidemia selama penelitian dan selama 3 bulan sebelum penelitian, tidak dalam keadaan sakit atau dalam perawatan dokter berkaitan dengan penyakit jantung koroner, diabetes mellitus, hipertensi, gagal ginjal, dan penyakit kronik lainnya, dan tidak alergi terhadap kacang tanah.

Perhitungan jumlah subyek pada penelitian ini menggunakan rumus uji hipotesis terhadap rerata dua populasi independen dan yang dibutuhkan pada setiap kelompok yaitu 10 orang. Subyek diperoleh dengan menggunakan metode consecutive sampling. Sebanyak 48 orang bersedia untuk menjalani proses skrinning awal seperti pengukuran berat badan, tinggi badan serta pemeriksaan darah. Berdasarkan proses skrinning tersebut diperoleh 26 orang yang memenuhi kriteria inklusi dan bersedia menjadi subyek penelitian. Tiap kelompok terdiri dari 11 orang, hal ini bertujuan untuk mengantisipasi terjadinya drop out pada subyek. Pengelompokkan subyek menjadi 2 kelompok perlakuan dilakukan dengan menggunakan metode simple random sampling. Kelompok perlakuan 1 mendapatkan intervensi kacang tanah rebus dan kelompok perlakuan 2 mendapatkan intervensi kacang tanah panggang. Pada saat pertengahan intervensi terdapat 6 orang subyek yang drop out sehingga tidak dapat menyelesaikan intervensi sampai akhir. Drop out pada subyek disebabkan karena adanya subyek yang sakit dan dinas luar kota. Pada akhir intervensi hanya didapatkan 8 orang pada tiap kelompok yang dapat menyelesaikan intervensi.

Dosis kacang tanah yang diberikan pada tiap kelompok yaitu 77 gram. Pemberian kacang tanah rebus dan panggang dilakukan selama 4 minggu. Pada penelitian ini, asupan makan seharihari pada kelompok perlakuan 1 dan kelompok perlakuan 2 tidak dikontrol. Pencatatan asupan makanan dilakukan sebelum dan selama intervensi menggunakan formulir food recall 24 yang kemudian dianalisis menggunakan program nutrisurvey 2005. Data asupan makanan ini digunakan untuk mengetahui apakah ada perubahan asupan makanan sebelum dan selama intervensi. Sampel darah diambil dari pembuluh darah vena pada pagi hari setelah subyek berpuasa selama \pm 10 jam. Pengambilan darah dan analisis dilakukan oleh salah satu laboratorium swasta di Semarang. Kadar kolesterol LDL dianalisis dengan cara pemeriksaan laboratorium menggunakan metode perhitungan kadar total kolesterol - kadar kolesterol HDL - 1/5 kadar trigliserida, sedangkan pemeriksaan kadar kolesterol HDL menggunakan metode phosphotungstic precipilation.

Pada penelitian ini, analisis data yang digunakan yaitu analisis univariat dan analisis bivariat. Analisis univariat digunakan untuk melihat data secara deskriptif yaitu melihat gambaran karakteristik subyek serta asupan makan subyek sebelum dan selama penelitian, sedangkan analisis bivariat digunakan untuk mengetahui hubungan masing-masing variabel. Data yang diperoleh kemudian diuji normalitasnya dengan menggunakan uji Shapiro-wilk $(\mathrm{n}<50)$. Perbedaan kadar kolesterol LDL dan HDL sebelum dan sesudah perlakuan pada masing - masing kelompok yang datanya berdistribusi normal akan dianalisis dengan paired $t$-test sedangkan data yang berdistribusi tidak normal akan dianalisis dengan uji non parametric Wilcoxon. Perbedaan kadar kolesterol LDL dan HDL antara kedua kelompok perlakuan yang datanya berdistribusi normal akan dianalisis dengan independent t-test sedangkan data yang berdistribusi tidak normal akan dianalisis dengan uji Mann-Whitney.

\section{HASIL PENELITIAN \\ Karakteristik Subyek Keseluruhan}

Karakteristik subyek keseluruhan penelitian ini disajikan pada tabel 1. Karakteristik ini bertujuan untuk melihat gambaran umum subyek sebelum intervensi secara keseluruhan.

Tabel 1. Karakteristik subyek keseluruhan

\begin{tabular}{lcc}
\hline Variabel & n & \% \\
\hline Umur & & $18.75 \%$ \\
$\mathbf{3 0 - 3 9}$ & 3 & $68.75 \%$ \\
$\mathbf{4 0 - 4 9}$ & 11 & $12.5 \%$ \\
$\mathbf{5 0 - 5 9}$ & 2 & $100 \%$ \\
\hline$\sum$ & 16 & $31.25 \%$ \\
\hline Status gizi & & \\
Overweight $\left(\mathbf{2 3 - 2 4 . 9} \mathbf{~ k g} / \mathbf{m}^{2}\right)$ & 5 & \\
\hline
\end{tabular}




\begin{tabular}{lcc}
\hline \multicolumn{1}{c}{ Obesitas $\left(>\mathbf{2 5} \mathbf{~ k g} / \mathbf{m}^{\mathbf{2}}\right)$} & 11 & $68.75 \%$ \\
\hline$\sum_{\begin{array}{l}\text { Kadar LDL awal } \\
\geq \mathbf{1 3 0} \mathbf{~ m g} / \mathbf{d l}\end{array}}$ & 16 & $100 \%$ \\
\hline$\sum$ & 16 & $100 \%$ \\
\hline $\begin{array}{l}\text { Kadar HDL awal } \\
\leq \mathbf{6 0} \mathbf{~ m g / d l}\end{array}$ & 16 & $100 \%$ \\
\hline$\sum$ & 16 & $100 \%$ \\
\hline
\end{tabular}

Berdasarkan tabel di atas diketahui bahwa secara keseluruhan, sebesar $68.75 \%$ subyek penelitian ini terdiri dari kelompok umur 40-49 tahun. Status gizi subyek pada penelitian ini sebagian besar $(68.75 \%)$ tergolong dalam kategori obesitas. Kadar LDL awal subyek pada penelitian ini seluruhnya $(100 \%)$ bernilai $\geq 130 \mathrm{mg} / \mathrm{dl}$ dan kadar HDL awal subyek bernilai $\leq 60 \mathrm{mg} / \mathrm{dl}$.

Karakteristik Subyek menurut Kelompok Intervensi

Karakteristik subyek pada kelompok rebus dan kelompok panggang disajikan pada tabel 2 .

Tabel 2. Karakteristik Subjek menurut Kelompok Intervensi

\begin{tabular}{|c|c|c|c|c|c|c|c|}
\hline \multirow{2}{*}{ Variabel } & \multicolumn{4}{|c|}{$\begin{array}{l}\text { Rebus } \\
(n=8)\end{array}$} & \multicolumn{2}{|c|}{$\begin{array}{c}\text { Panggang } \\
(\mathrm{n}=8)\end{array}$} & \multirow{2}{*}{$\mathbf{p}^{1}$} \\
\hline & Rerata \pm SB & $\mathbf{n}$ & $\%$ & Rerata \pm SB & $\mathbf{n}$ & $\%$ & \\
\hline $\begin{array}{l}\text { Umur } \\
30-39 \\
40-49 \\
50-59 \\
\end{array}$ & $42.49 \pm 6.65$ & $\begin{array}{l}2 \\
6 \\
0\end{array}$ & $\begin{array}{l}25 \% \\
75 \%\end{array}$ & $47.00 \pm 4.71$ & $\begin{array}{l}1 \\
5 \\
2\end{array}$ & $\begin{array}{l}12.5 \% \\
62.5 \% \\
25 \%\end{array}$ & $\begin{array}{c}0.13 \\
9\end{array}$ \\
\hline $\begin{array}{l}\text { Status Gizi } \\
\text { Overweight } \\
\left.\mathrm{kg} / \mathrm{m}^{2}\right) \\
\text { Obesitas }\left(>25 \mathrm{~kg} / \mathrm{m}^{2}\right)\end{array}$ & $28.10 \pm 2.76$ & 1 & $\begin{array}{l}12.5 \% \\
87.5 \%\end{array}$ & $26.09 \pm 2.85$ & 4 & $\begin{array}{l}50 \% \\
50 \%\end{array}$ & $\begin{array}{c}0.17 \\
5\end{array}$ \\
\hline $\begin{array}{l}\text { Kadar LDL awal } \\
\geq 130 \mathrm{mg} / \mathrm{dl}\end{array}$ & $\begin{array}{c}161.82 \pm 27.3 \\
5 \\
\end{array}$ & 8 & $100 \%$ & $\begin{array}{c}159.82 \pm 16.5 \\
6\end{array}$ & 8 & $100 \%$ & $\begin{array}{c}0.86 \\
2\end{array}$ \\
\hline $\begin{array}{l}\text { Kadar HDL awal } \\
\leq 60 \mathrm{mg} / \mathrm{dl}\end{array}$ & $48.87 \pm 3.35$ & 8 & $100 \%$ & $43.87 \pm 5.93$ & 8 & $100 \%$ & $\begin{array}{c}0.05 \\
7\end{array}$ \\
\hline
\end{tabular}

\section{Independent t-test}

Sebagian besar subyek dalam penelitian ini baik pada kelompok panggang maupun kelompok rebus berada pada kelompok umur 40-49 tahun dan status gizi obesitas. Berdasarkan hasil uji beda independent $t$-test diketahui bahwa tidak terdapat perbedaan umur, status gizi, kadar LDL, dan kadar HDL sebelum penelitian antara kedua kelompok ( $>0.05)$. Hal ini menunjukkan bahwa karakteristik awal subyek pada kelompok rebus dan panggang adalah bersifat homogen.

Perbedaan Kacang Tanah Rebus dan Panggang terhadap Kadar LDL dan HDL

Perbedaan pengaruh kacang tanah rebus dan panggang terhadap kadar LDL dan HDL disajikan pada tabel 3 .

Tabel 3. Perbedaan Pengaruh Kacang Tanah Rebus dan Panggang terhadap Kadar LDL dan HDL

\begin{tabular}{lccc}
\hline \multirow{2}{*}{ Variabel } & Rebus $(\mathbf{n}=\mathbf{8})$ & Panggang $(\mathbf{n}=\mathbf{8})$ & \multirow{2}{*}{$\mathbf{p}$} \\
\cline { 2 - 3 } & Rerata \pm SB & Rerata \pm SB & \\
LDL $(\mathbf{m g} / \mathbf{d l})$ & $161.82 \pm 27.35$ & $159.82 \pm 16.56$ & \\
Awal & $157.70 \pm 28.66$ & $135.67 \pm 31.26$ & \multirow{2}{*}{$\mathbf{0 . 0 8 0}^{\mathbf{1}}$} \\
Akhir & $-4.12 \pm 16.40$ & $-24.15 \pm 25.07$ & \\
$\boldsymbol{\Delta}$ & & &
\end{tabular}




\begin{tabular}{lccc} 
p & $\mathbf{0 . 5}^{\mathbf{a}}$ & $\mathbf{0 . 0 3}^{\mathbf{a}^{*}}$ & \\
\hline HDL (mg/dl) & & & \\
Awal & $48.87 \pm 3.35$ & $43.87 \pm 5.93$ & \\
Akhir & $45.00 \pm 8.03$ & $45.87 \pm 6.99$ & \\
$\boldsymbol{\Delta}$ & $-3.87 \pm 7.71$ & $2.00 \pm 6.09$ & $\mathbf{0 . 1 1 3}^{\mathbf{1}}$ \\
$\mathbf{p}$ & $\mathbf{0 . 1 9 9}^{\mathbf{a}}$ & $\mathbf{0 . 3 8 4}^{\mathbf{a}}$ & \\
\hline
\end{tabular}

1 Independent $t$-test

2 uji Mann-Whitney

a Paired t-test

b uji Wilcoxon

* Beda bermakna $(\mathrm{p}<0.05)$

Berdasarkan tabel 3, diketahui bahwa tidak terdapat perbedaan rerata kadar LDL sebelum dan setelah intervensi pada kelompok rebus $(p>0.05)$ namun terdapat perbedaan rerata kadar LDL yang bermakna sebelum dan setelah intervensi pada kelompok panggang $(\mathrm{p}<0.05)$. Tidak terdapat perbedaan rerata perubahan kadar LDL antara kelompok rebus dan panggang $(\mathrm{p}>0.05)$.

Tidak terdapat perbedaan rerata kadar HDL yang bermakna sebelum dan setelah intervensi pada masing-masing kelompok, selain itu, tidak terdapat perbedaan rerata perubahan kadar HDL antara kelompok rebus dan panggang $(\mathrm{p}>0.05)$

Asupan Makan Sebelum dan Selama Intervensi Asupan makan sebelum dan selama intervensi pada kelompok rebus dan panggang disajikan pada tabel 4. Analisis asupan sebelum dan selama intervensi ini bertujuan untuk mengetahui apakah ada perubahan asupan pada saat sebelum dan selama intervensi.

Tabel 4. Asupan makan sebelum dan selama intervensi

\begin{tabular}{|c|c|c|c|}
\hline \multirow[t]{2}{*}{ Asupan makan } & $\begin{array}{c}\text { Rebus } \\
(n=8)\end{array}$ & $\begin{array}{c}\text { Panggang } \\
(\mathrm{n}=8)\end{array}$ & \multirow[t]{2}{*}{$\mathbf{p}$} \\
\hline & Rerata \pm SB & Rerata \pm SB & \\
\hline \multicolumn{4}{|l|}{ Energi } \\
\hline Awal & $1461.48 \pm 467.27$ & $1308.62 \pm 288.77$ & \multirow{4}{*}{0.314} \\
\hline Intervensi & $1383.60 \pm 214.57$ & $1465.19 \pm 161.93$ & \\
\hline$\Delta$ & $-77.87 \pm 595.04$ & $156.57 \pm 220.62$ & \\
\hline $\mathbf{P}$ & 0.722 & 0.085 & \\
\hline \multicolumn{4}{|l|}{ Protein } \\
\hline Awal & $54.36 \pm 19.42$ & $50.20 \pm 13.57$ & \multirow{4}{*}{0.297} \\
\hline Intervensi & $52.19 \pm 10.27$ & $58.29 \pm 10.79$ & \\
\hline$\Delta$ & $-2.17 \pm 25.32$ & $8.08 \pm 8.66$ & \\
\hline p & 0.815 & $0.034 *$ & \\
\hline \multicolumn{4}{|l|}{ Lemak } \\
\hline Awal & $61.02 \pm 25.29$ & $58.60 \pm 16.28$ & \multirow{4}{*}{0.114} \\
\hline Intervensi & $64.29 \pm 12.25$ & $81.00 \pm 7.51$ & \\
\hline$\Delta$ & $3.27 \pm 28.44$ & $22.39 \pm 14.92$ & \\
\hline $\mathbf{p}$ & 0.754 & $0.004^{*}$ & \\
\hline \multicolumn{4}{|l|}{ Lemak Jenuh } \\
\hline Awal & $24.97 \pm 9.02$ & $24.61 \pm 6.48$ & \multirow{4}{*}{$0.529^{2}$} \\
\hline Intervensi & $22.16 \pm 5.21$ & $23.24 \pm 4.65$ & \\
\hline$\Delta$ & $-2.80 \pm 11.67$ & $-1.36 \pm 7.39$ & \\
\hline $\mathbf{p}$ & 0.519 & 0.617 & \\
\hline \multicolumn{4}{|l|}{ MUFA } \\
\hline Awal & $15.92 \pm 6.63$ & $14.25 \pm 5.45$ & \multirow{4}{*}{$0.004 *$} \\
\hline Intervensi & $20.38 \pm 3.77$ & $29.49 \pm 3.26$ & \\
\hline$\Delta$ & $4.46 \pm 7.28$ & $15.23 \pm 5.24$ & \\
\hline p & 0.127 & $0.012^{\mathrm{b}} *$ & \\
\hline
\end{tabular}




\begin{tabular}{lccc}
\hline PUFA & & & \\
Awal & $15.51 \pm 9.76$ & $15.52 \pm 6.75$ & \\
Intervensi & $17.35 \pm 5.85$ & $23.28 \pm 3.22$ & 0.095 \\
$\boldsymbol{\Delta}$ & $1.83 \pm 8.44$ & $7.75 \pm 4.05$ & \\
$\mathbf{p}$ & $0.779^{\mathrm{b}}$ & $0.001^{*}$ & \\
\hline Karbohidrat & & & \\
Awal & $180.87 \pm 63.76$ & $149.75 \pm 37.77$ & \\
Intervensi & $155.70 \pm 41.06$ & $133.28 \pm 23.70$ & 0.768 \\
$\boldsymbol{\Delta}$ & $-25.17 \pm 75.84$ & $-16.47 \pm 30.19$ & \\
$\mathbf{p}$ & 0.379 & 0.167 & \\
\hline Kolesterol & & & \\
Awal & $212.35 \pm 92.06$ & $234.77 \pm 101.31$ & \\
Intervensi & $202.74 \pm 115.55$ & $134.09 \pm 117.65$ & \\
$\boldsymbol{\Delta}$ & $-9.61 \pm 160.22$ & $-100.67 \pm 144.41$ & \\
$\mathbf{p}$ & $0.674^{\mathrm{b}}$ & 0.089 & \\
\hline Serat & & & \\
Awal & $9.87 \pm 3.31$ & $7.94 \pm 2.63$ & \\
Intervensi & $13.05 \pm 3.30$ & $14.04 \pm 3.14$ & \\
$\boldsymbol{\Delta}$ & $3.17 \pm 3.72$ & $6.09 \pm 1.98$ & \\
$\mathbf{p}$ & $0.047^{*}$ & $0.000^{*}$ & \\
\hline
\end{tabular}

1 Independent $t$-test

2 uji Mann-Whitney

a Paired t-test

b uji Wilcoxon

* Beda bermakna $(\mathrm{p}<0.05)$

Berdasarkan tabel 4, diketahui bahwa terdapat peningkatan yang bermakna pada asupan lemak, MUFA, dan PUFA sebelum dan selama intervensi pada kelompok panggang $(\mathrm{p}<0.05)$. Terdapat peningkatan yang bermakna pada asupan serat sebelum dan selama intervensi pada kedua kelompok $(\mathrm{p}<0.05)$, namun tidak terdapat perbedaan perubahan asupan antara kedua kelompok $(p>0.05)$. Terdapat perbedaan yang bermakna pada perubahan asupan MUFA antara kedua kelompok $(\mathrm{p}<0.05)$.

\section{PEMBAHASAN}

Karakteristik subyek dalam penelitian ini adalah wanita dengan IMT $>23.00 \mathrm{~kg} / \mathrm{m}^{2}$ yang belum mengalami menopause. Sebagian besar subyek dalam penelitian ini termasuk dalam kategori umur 40-49 tahun. Kategori umur 40 - 49 tahun merupakan masa pre menopause yang menyebabkan produksi hormon estrogen semakin berkurang sedangkan hormon estrogen ini merupakan hormon protektif pada wanita untuk mencegah terjadinya peningkatan kadar kolesterol LDL dan penurunan kadar kolesterol HDL. Kategori umur 40 - 49 tahun ini memiliki risiko yang lebih besar dalam kenaikan kadar LDL dibandingkan wanita produktif, selain itu, kadar LDL semakin meningkat seiring dengan bertambahnya umur. Hal ini disebabkan karena berkurangnya aktivitas reseptor LDL. ${ }^{5}$

Pada penelitian ini, sebagian besar status gizi subyek berdasarkan Indeks Massa Tubuh (IMT) adalah tergolong obesitas. Persentase lemak tubuh wanita lebih tinggi dibandingkan pria. Jaringan adiposa yang berlebih sangat mempengaruhi terjadinya penyakit kardiovaskuler melalui beberapa faktor risiko seperti meningkatnya kadar LDL dan menurunnya kadar HDL. Jaringan adiposa yang berlebih pada penderita obesitas akan menyediakan banyak trigliserida untuk membantu sintesis VLDL. Pada sirkulasi darah, trigliserid di VLDL akan mengalami hidrolisis oleh enzim lipoprotein lipase (LPL) yang akan mengubah VLDL menjadi IDL, setelah itu IDL kembali dihidrolisis menjadi LDL yang tinggi kolesterol. ${ }^{1,2}$ Kadar kolesterol LDL subyek adalah $\geq 130 \mathrm{mg} / \mathrm{dl}$, kadar ini tergolong dalam kategori tinggi. Selain itu, kadar HDL subyek adalah $\leq 60 \mathrm{mg} / \mathrm{dl}$, kadar ini memiliki risiko untuk mengalami dislipidemia. ${ }^{1,2,12}$

Rerata kadar LDL awal pada kelompok rebus yaitu $161.82 \mathrm{mg} / \mathrm{dl}$ dan kelompok panggang yaitu $159.82 \mathrm{mg} / \mathrm{dl}$ sementara itu rerata kadar HDL awal pada kelompok rebus yaitu $48.87 \mathrm{mg} / \mathrm{dl}$ dan kelompok panggang yaitu $43.87 \mathrm{mg} / \mathrm{dl}$. Berdasarkan hasil uji statistik independent t-test, 
diketahui bahwa tidak terdapat perbedaan umur, status gizi, kadar LDL, dan kadar HDL sebelum intervensi, begitu juga dengan asupan makan sebelum intervensi antara kedua kelompok. Hal ini menunjukkan bahwa karakteristik awal subyek pada penelitian ini adalah bersifat homogen. Kondisi yang homogen ini bermanfaat untuk meminimalisir risiko terjadinya hasil yang rancu pada akhir penelitian.

Pada penelitian ini, pemberian kacang tanah rebus dan panggang dapat berpengaruh menurunkan kadar LDL. Pada kelompok rebus terjadi penurunan kadar LDL sebesar $4.12 \mathrm{mg} / \mathrm{dl}$ (2.54\%) namun penurunan ini tidak bermakna secara statistik dan pada kelompok panggang terjadi penurunan yang bermakna sebesar 24.15 $\mathrm{mg} / \mathrm{dl}(15.11 \%)$. Secara statistik, tidak terdapat perbedaan penurunan kadar LDL antara kelompok rebus dan panggang, namun secara deskriptif, pemberian kacang panggang memberikan efek penurunan yang lebih besar.

Penurunan kadar kolesterol LDL yang signifikan pada kelompok panggang ini dapat disebabkan karena kandungan Mono Unsaturated Fatty Acid (MUFA) dalam 77 gram kacang panggang lebih besar dari pada kacang rebus. Kandungan MUFA dalam 77 gram kacang panggang yaitu sebanyak 18.942 gram sedangkan dalam kacang rebus sebanyak 8.409 gram. ${ }^{13,14}$ Kandungan MUFA ini kemungkinan dapat memicu meningkatkan aktivitas reseptor LDL dalam tubuh.

Selain MUFA, kacang tanah juga mengandung serat yang berfungsi untuk menurunkan kadar LDL dalam darah. Sebanyak 77 gram kacang tanah panggang mengandung lebih banyak serat yaitu 7.287 gram sedangkan dalam kacang rebus sebanyak 6.875 gram. ${ }^{12,13}$ Serat ini akan mengikat asam empedu dan kolesterol berlebih yang kemudian akan diekskresi melalui feses. Hal ini menyebabkan asam empedu yang kembali disirkulasi di siklus enterohepatik menjadi berkurang, oleh karena itu dibutuhkan kolesterol kembali untuk disintesis menjadi asam empedu dalam jumlah yang sama sehingga asam empedu dalam sirkulasi dapat dipertahankan konstan. Hal inilah yang menyebabkan penurunan kadar kolesterol dalam darah. Selain itu, fermentasi serat di kolon menghasilkan propionat (asam lemak rantai pendek) yang akan diabsorbsi ke dalam vena porta. Asam lemak rantai pendek ini dapat menghambat aktivitas HMG CoA reduktase yang merupakan suatu enzim untuk menyintesis kolesterol. Hal ini menyebabkan menurunnya sintesis kolesterol. Kolesterol LDL merupakan lipoprotein dengan kandungan kolesterol tertinggi yaitu mencapai $45 \%$, dengan terhambatnya sintesis kolesterol oleh serat maka secara tidak langsung akan menghambat sintesis kolesterol LDL. ${ }^{16,17,18}$

Pada kelompok rebus terjadi penurunan kadar HDL yang tidak bermakna sebesar 3.87 $\mathrm{mg} / \mathrm{dl} \quad(7.91 \%)$ sementara itu pada kelompok panggang terjadi peningkatan kadar HDL yang tidak bermakna sebesar $2 \mathrm{mg} / \mathrm{dl}(4.55 \%)$. Secara statistik, tidak terdapat perbedaan peningkatan kadar HDL antara kelompok rebus dan panggang ( $>0.05)$, namun secara deskriptif kacang panggang lebih berpengaruh dalam meningkatkan kadar HDL. Peningkatan kadar HDL pada kelompok panggang dapat disebabkan karena adanya kandungan Poly Unsaturated Fatty Acid (PUFA) yang lebih besar pada kacang panggang dibandingkan dengan kacang rebus. Kandungan PUFA dalam 77 gram kacang panggang yaitu sebesar 12.089 gram sedangkan dalam 77 gram kacang rebus sebesar 5.357 gram. ${ }^{13,14}$

Rerata asupan MUFA pada kelompok panggang mengalami peningkatan yang lebih besar dan bermakna dibandingkan dengan kelompok rebus. Peningkatan asupan MUFA pada kelompok panggang yaitu sebesar 15.23 gram sedangkan pada kelompok rebus sebesar 4.46 gram. Secara statistik, terdapat perbedaan yang bermakna antara asupan MUFA pada kelompok panggang dan rebus. Rerata peningkatan asupan PUFA pada kelompok panggang juga lebih besar dan bermakna dibandingkan dengan kelompok rebus yaitu sebesar 7.75 gram pada kelompok panggang dan sebesar 1.83 gram pada kelompok rebus, namun secara statistik, tidak terdapat perbedaan antara kelompok rebus dan panggang. Selain itu, rerata peningkatan asupan serat lebih besar terjadi pada kelompok panggang yaitu sebesar 6.09 gram sedangkan pada kelompok rebus sebesar 3.17 gram. Rerata peningkatan asupan MUFA, PUFA, dan serat yang lebih besar pada kelompok panggang juga dapat mempengaruhi perubahan kadar kolesterol LDL dan HDL.

Rerata asupan kolesterol pada kelompok panggang mengalami penurunan yaitu dari 234.77 mg menjadi $134.09 \mathrm{mg}$ sedangkan pada kelompok rebus mengalami perubahan yaitu dari $212.35 \mathrm{mg}$ menjadi 202.74 mg. Berdasarkan American Heart Association (AHA) dan Therapeutic Lifestyle Change (TLC), anjuran asupan kolesterol adalah sebesar < $200 \mathrm{mg} / \mathrm{hari}$. Pada kelompok rebus, rerata asupan kolesterol selama intervensi sebesar 202.74, kemungkinan hal inilah yang 
menyebabkan penurunan kadar LDL pada kelompok rebus tidak terlalu signifikan. ${ }^{5}$

\section{SIMPULAN}

Tidak terdapat perbedaan penurunan kadar kolesterol LDL dan HDL antara kelompok rebus dan panggang $(\mathrm{p}>0.05)$.

\section{DAFTAR PUSTAKA}

1. Lysen LK, Israel DA. Nutrition in Weight Management. In : L Kathleen Mahan, Sylvia EscottStump, editors. Krause's Food and Nutrition Therapy. $13^{\text {th }}$ edition. Philadelphia,USA - Saunders Elsivier; 2012.p.462;26.

2. Sugondo S. Obesitas. Dalam : Sudoyo AW, Hasi BS, Alwi I, Simadibrata M, Setiati S, editor. Buku Ajar Ilmu Penyakit Dalam. Edisi 4. Jakarta : PP IPD FK UI; 2006.p.1919;6.

3. World Health Organization. World Health Statistics. 2012.

4. Laporan Hasil Riset Kesehatan Dasar (RISKESDAS) Nasional. 2011.

5. Raymond JL, Couch SC. Medical Nutrition Therapy for Cardiovasculer Desease. In : L Kathleen Mahan, Sylvia Escott-Stump, editors. Krause's Food and Nutrition Therapy. $13^{\text {th }}$ edition. Philadelphia,USA Saunders Elsivier; 2012.p.742;34.

6. Sloan K, Vacek JL. Treatment of Dyslipidemia. Journal of Clinical Metabolism \& Diabetes. 2011.

7. Stephens AM, Lisa LD, Jack PD, Jason AO, Timothy HS. Peanuts, Peanut Oil, and Fat Free Peanut Flour Reduced Cardiovascular Disease Risk Factors and the Development of Atherosclerosis in Syrian Golden Hamsters. Journal of Food Science 2010;75:116-122.

8. Nouran MG, Kimiagar M, Abadi A, Mirzazedah M, Harrison G. Peanut Consumption and Cardiovascular Risk. Public Health Nutrition 2010; 13(10):1581-1586.

9. Segura R, Javierre C, Lizzaraga MA, Ros E. Other Relevant Components of Nuts : Phytosterol, Folate, and Minerals. British Journal of Nutrition 2006;96(suppl.2):S36-S44.

10. Eherteon PMK, Thomas AP, Ying Wan, Rebecca LH, Kristin M, Valerie F, et all. HighMonounsaturated Fatty Acid Diets Lower Both Plasma Cholesterol and Triacylglycerol Concentrations. Am J Clin Nutr 1999;70:1009-15.

11. Hargove RL, Terry DE, Thomas AP, Earl HH, Penny MKE. Low fat and High Monounsaturated Fat Diets Decrease Human Low Density Lipoprotein Oxidative Susceptibility In Vitro. J. Nutr 2011;131:1758-1763.

12. Adam JMF. Dislipidemia. Dalam : Sudoyo AW, Hasi BS, Alwi I, Simadibrata M, Setiati S, editor. Buku Ajar Ilmu Penyakit Dalam. Edisi 4. Jakarta : PP IPD FK UI; 2006.p.1926;7.
13. Ros E. Nuts and Novel Biomarkers of Cardiovascular Disease. Am J Clin Nutr 2009;89(suppl):1649s-56s.

14. Fraser G. Nut Consumption, Lipids, and Risk Coronary Event. Clin. Cardiol. 22 (suppl III).1999.

15. Griffin BA. Nutrition and Metabolism of Lipids. In: Michael J Gibney, Susan A Lanham-New, editor. Introduction to Human Nutrition Second edition. UK; 2009.p86-121.

16. Jeffery EH, Susan MK, Anna SK. Nonessential food Components With Health Benefits. In : Yvonne Alexopolous. Biochemical, Physiological, \& Molecular Aspects of Human Nutrition. $2^{\text {nd }}$ edition. USA: Saunders Elsevier; 2006.p.13-38.

17. Lupton J, Turner ND. Dietary Fiber. In : Yvonne Alexopolous. Biochemical, Physiological, \& Molecular Aspects of Human Nutrition. $2^{\text {nd }}$ edition. USA: Saunders Elsevier; 2006.p.240-253.

18. Gropper SS, Smith JL, Groff JL. Fiber. In : Advanced Nurition and Human Metabolism. $5^{\text {th }}$ edition. USA : Wadsworth; 2009.p 107-121. 